Jap. J. Limnol. 42, 3, 176-179, 1981.

\title{
NOTE \\ The Behaviour of Methylene Blue Active Substances (MBAS) \\ in Bottom Muds under Laboratory Conditions
}

\author{
Masahiro UCHIYAMA
}

\begin{abstract}
The present study was carried out in order to clarify the behaviour of MBAS in the bottom muds, especially with regard to the interaction between the interstitial water and the bottom mud particles.

It was speculated that, after diffusing into the interstitial water of the bottom muds from overlying water, MBAS is adsorbed on the mud particles and accumulated in the bottom muds. In the bottom muds, there is an equilibrium between MBAS in dissolved form in the interstitial water and in adsorbed form on the mud particles. This equilibrium is changed easily by various conditions, e.g., by water temperature, electric conductivity of water and the MBAS concentration in the water column.
\end{abstract}

\section{Introduction}

There have been some reports about the distribution of MBAS in freshwater regions (АмBE, 1972; UсHIYAMA, 1979; UсHIYAMA and YAMAGUCHI, 1980) but only a few on the behaviour of MBAS, especially in the bottom muds.

KAMIYAMA et al. (1977) studied the release of ammonium nitrogen from the bottom sediments in freshwater regions and showed that ammonium nitrogen there may be classified into two types, one dissolved in interstitial water and the other adsorbed on the mud particles. The same authors emphasized that the adsorption or the desorption in the mud particles-interstitial water system should be taken into consideration in order to apply the diffusion process and to clarify the movement of ammonium nitrogen in the bottom sediments.

\section{Experimental and Results}

MBAS analyses were run according to the "Standard Method" (American Public Health, 1971). Sodium dodecyl benzene sulfonate was used as the standard material. The bottom muds used in this experiment were collected from a tiny basin into which the domestic effluents were flowed. MBAS was extracted from the bottom muds by the ultrasonic extraction method described in the previous report (UchiYAma and TAKamURA, 1980). About $10 \mathrm{~g}$ of wet mud was extracted three times ultrasonically with $100 \mathrm{ml}$ methanol. After the methanol was evaporated, the residue was dissolved in $100 \mathrm{~m} l$ distilled water by the ultrasonic method and the solution was used for determining MBAS.

1. MBAS in the interstitial water of the bottom muds.

Kamiyama et al. (1977) showed that the pressure used in separating the interstitial water of the bottom sediments had little effect on the concentration of ammonium nitrogen in the interstitial water, irrespective of the amount obtained in the separation. However, little information has been obtained about MBAS in the interstitial water of the bottom muds. Therefore the concentration of MBAS in the interstitial water which was separated by centrifugation at various pressure was determined. A definite pressure level was obtained by controlling the rotary speed, and was expressed as $\mathrm{pF}$ (KAWAGUCHI et al., 1976).

In general, the water separated from mud at less than about $\mathrm{pF} 2.0$ is gravita- 
tional water, and that between $\mathrm{pF} 2.0$ and $\mathrm{pF} 4.5$ is capillary water.

$$
\mathrm{pF}=\log \underset{\mathrm{g}}{\mathrm{r}}\left(\frac{\pi \mathrm{n}}{30^{-}}\right)^{2}
$$

where $\mathrm{r}$; radius of rotor $(\mathrm{cm})$

g; gravity constant, $980\left(\right.$ dyne $\left./ \mathrm{cm}^{2}\right)$

$\mathrm{n}$; rotary speed (round per minute)

The centrifugation was carried out at room temperature for 30 minutes. The pressure was changed from $\mathrm{pF} 1.6$ to $\mathrm{pF} 3.6$. After the gravitational water was separated at $\mathrm{pF} 1.6$, the pressure was changed and the concentration of MBAS in the separated water and the moisture content in the mud were determined.

With the increase in the pressure, the residual moisture content decreased and the amount of separated interstitial water increased. The pressure had little effect on the MBAS concentration in the interstitial water independent of the amount obtained in the separation. This result was just the same as that for ammonium nitrogen shown by KАMIYAMA et al. (1977).

From these results, it was speculated that the interstitial water surrounding the mud particles is almost uniform in MBAS concentration and that there is an equilibrium between the concentration of MBAS in dissolved form in the interstitial water and in adsorbed form on the mud particles. If this speculation is true, it would be possible to change this equilibrium by changing the conditions of the mud particles. In the next experiments, the amount of extracting water, water temperature and the concentration of $\mathrm{NaCl}$ in the extracting water were chosen for the conditions to be changed.

2. Extraction of MBAS from the bottom mud with various amounts of water.

MBAS in the bottom mud sample was extracted by shaking for 2 hours with various amounts of distilled water and then the supernatant was removed. The concentration of MBAS in the supernatant was measured.

Figure 1 shows the relationship between the amount of distilled water and the amount of MBAS extracted from the mud.

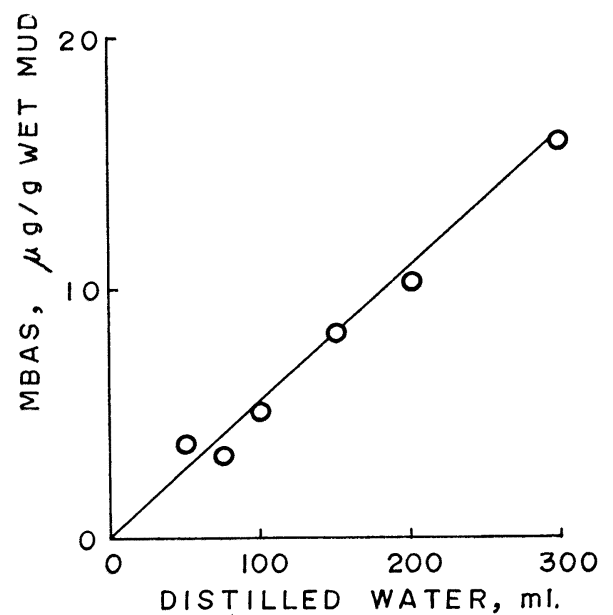

Fig. 1. The effect of the amount of distilled water on the concentration of MBAS in the supernatant of mud - water mixtures.

It is clear from this figure that the amount of MBAS extracted from the bottom mud was increased by increasing the amount of distilled water. It is supposed that the liberation of MBAS from the bottom mud results from the fact that the equilibrium between MBAS in dissolved form in the interstitial water and in adsorbed form on the mud particles is destroyed by the addition of distilled water, and that a new equilibrium is attained between two forms of MBAS.

3. Effect of water temperature on the equilibrium of MBAS in the adsorbed and dissolved form in the bottom mud.

Ten $\mathrm{g}$ of wet mud and $200 \mathrm{~m} l$ of distilled water in $300 \mathrm{~m} l$ Erlenmyer flask were stirred initially at $4^{\circ} \mathrm{C}$ for 24 hours, and then at different temperatures for 24 hours. After that, the supernatant was separated and used for determining the amount of MBAS. At the same time, each of the other samples thus incubated was stirred again at $4^{\circ} \mathrm{C}$ for 24 hours and then the supernatant "was removed and used for determining the amount of MBAS. Figure 2 shows the results of this experiment. The biodegradation of MBAS may occur because the mud is treated at a high temperature for a long time. Then the mud sample was autoclaved for 60 minutes 


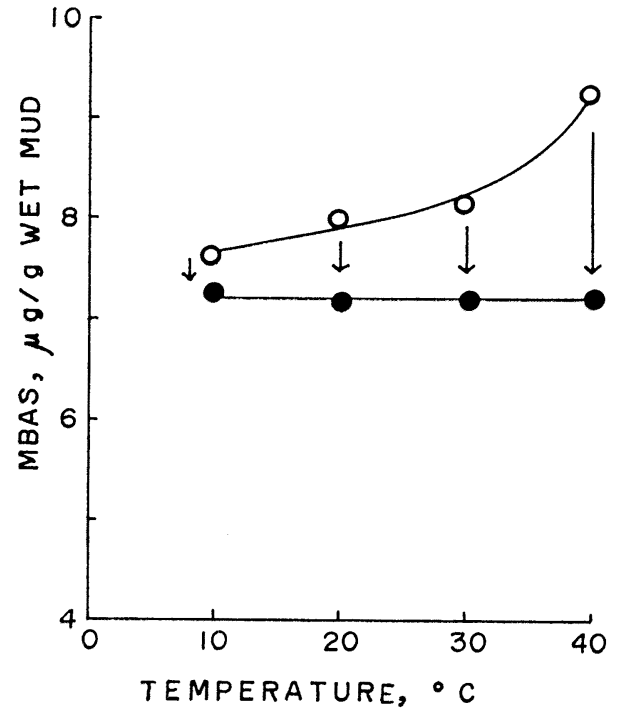

Fig. 2. The effect of the water temperature on the concentration of MBAS in the supernatant of mud - water mixtures.

: 24 hours at $4^{\circ} \mathrm{C}$ (initial level) $\bigcirc: 24$ hours at each temperature Arrows show the restoration to initial level by lowering the temperature.

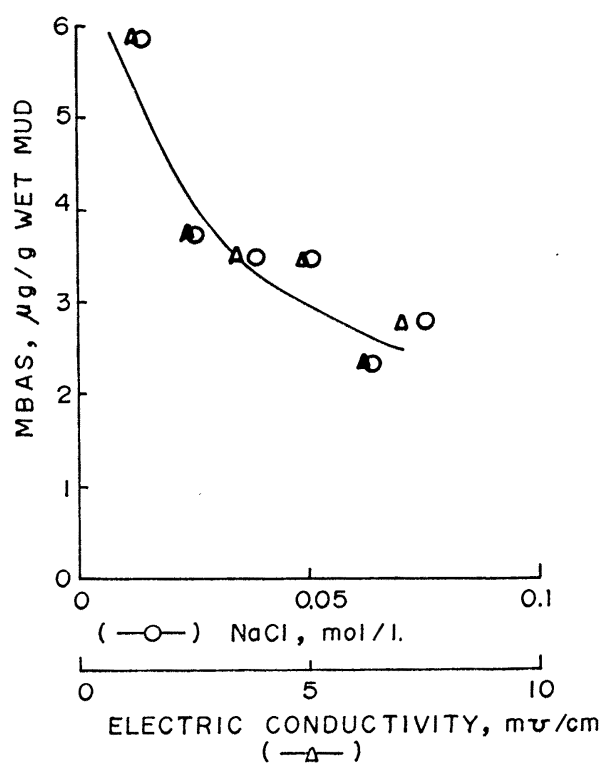

Fig. 3. The effect of the concentration of $\mathrm{NaCl}$ on the concentration of MBAS in the supernatant of mud-water mixtures. at $121^{\circ} \mathrm{C}-123^{\circ} \mathrm{C}$ before use. The arrows in the figure indicate the changes in the MBAS concentration resulting from lowering the temperature of each mixture to $4^{\circ} \mathrm{C}$. As shown in Fig. 2 , the amount of MBAS adsorbed on the mud particles decreased with increase in the temperature of the mixture and was restored to the initial level by lowering the temperature.

\section{Effect of concentration of sodium chloride.}

Twenty $\mathrm{g}$ wet mud was mixed with 200 $\mathrm{m} l$ of sodium chloride solution with various concentrations $(0.013-0.075 \mathrm{~mol} / l)$, and then stirred for 2 hours at room temperature. The supernatant was separated and used for the determination of MBAS. The electric conductivity of the supernatant was also measured. Figure 3 presents the results of this experiment, showing that the concentration of MBAS in the supernatant decreased with increasing the concentration of $\mathrm{NaCl}$ as an extractant. The results demonstrate that MBAS adsorbed on mud particles was liberated into the supernatant by a decrease in the sodium chloride concentration and that a new equilibrium between the two forms of MBAS was attained.

\section{Discussion and Conclusion}

UCHIYAMA and YAMAGUCHI (1980) reported that the form of MBAS in water is almost dissolved, so the diffusion of MBAS into the interstitial water of the bottom muds from overlying water may play the most important role in MBAS accumulation in the bottom muds.

From these results, the process of MBAS accumulation in the bottom muds and overlying water system will be as follows:

After diffusing into the interstitial water of the bottom muds from the overlying water, MBAS is adsorbed on the mud particles and accumulated in the bottom muds. In the bottom muds, there is an equilibrium between MBAS in dissolved form in the interstitial water, and a new equilibrium is attained by the changes in the conditions (e.g., water temperature, 
ion strength of water and MBAS concentration in water column).

\section{摘要}

本報においては，低䓄中のメチレンブルー活性物質 (MBAS) の挙動总明らかてするととを目的とし，特 に，低質粒子と間げき水との相互作用に注目した。

水一低質界面において，MBAS は底質中の間げき 水中へを拡散した後に底質粒子への收着党起こすもの と思わ机る，戍颃中においては，間げき水中に浴解し ている MBAS と，底䓄粒子に吸着した MBAS との 間で平衡状態が成立しているものと思われるが，ての 平衡状態は，底質をとりまく条件，たとえば水温，水 の電気伝導度, 水中の MBAS 浱度の変化により容易 にくずれ，再び新たな平衡状態が成立する，てのよう な底質粒子一間げき水間の平衡状態の変化を伴いなが

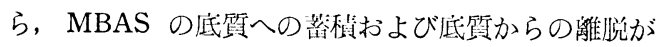
起てっていることが推定された。

\section{References}

Ambe, Y. (1972) : Distribution of MBAS (alkylbenzenesulfonate) in the bottom muds of lake Suwa. Jap. J. Limnol., 33: 44-50 (in Japanese).

American Public Health Association. (1971): Standard Method for the Examination of Water and Wastewater. (13th. ed.) American
Public Health Association. New York.

Kamiyama, K., S. Okuda and A. Kawai, (1977) : Studies on the release of ammonium nitrogen from the bottom sediments in freshwater regions. Jap. J. Limnol., 38: 100-106.

Kawaguch, K., K. Kumada, S. Aomine, C. Furusaka, H. Okajima, S. Sasaki, Y. Takai, I. Yamane, and S. Funabiki (1976) : Dojyo Gaku (Pedology). Asakura publishing corp. Tokyo. (in Japanese).

Uchiyama, M. (1979) : Separation and determination of fluorescent whitening agent and alkylbenzenesulfonate in water. Water Res., 13: 847-853.

Uchiyama, M. and M. Takamura, (1980): The method for extracting methylene blue active substances from the bottom muds. Jap. J. Water Poll. Res., 3:133-136 (in Japanese).

Uchiyama, M. and M. Yamaguchi (1980): The distribution and behaviour of methylene blue active substances. Jap. J. Water Poll. Res., 3:177-182 (in Japanese).

（著者：以山征洋, 群熙県衛生公害研究所, 前橋市 岩神町; Masahiro Uchiyama, Gunma Institute of Public Health, Iwagami-chyo, Maebashi 371).

Accepted: 5 March 1981 